Jpn. J. Med. Sci. Biol., 43, 15 - 18, 1990.

Short Communication

\title{
PREVALENCE OF SPOTTED FEVER GROUP RICKETTSIA ANTIBODY IN APODEMUS SPECIOSUS CAPTURED IN AN ENDEMIC FOCUS IN MIYAZAKI PREFECTURE, JAPAN
}

Chiharu MORITA, Seigo YAMAMOTO1, Kimiyuki TSUCHIYA2, Yoshiya YOSHIDA33, Tatuo YABE3, Norihiko KAWABATA1

and Masanobu FUKUI

Department of Veterinary Science, National Institute of Health, Kamiosaki, Shinagawa-ku, Tokyo 141, 1Miyazaki Prefectural Public Health Laboratory, Kitatakamatsu-cho, Miyazaki-shi, Miyazaki 880, 2Experimental Animal Center, Miyazaki Medical College, Kiyotake-cho, Miyazaki-gun, Miyazaki 889-16 and 3 Kanagawa Prefectural Public Health Laboratories, Nakao-cho, Asahi-ku, Yokohama, Kanagawa 241

(Received January 8, 1990. Accepted March 23, 1990)

SUMMARY: Fourteen of Apodemus speciosus (large Japanese field mouse) were captured near the place where one of the patients with spotted fever group rickettsiosis had been infected, in Takaoka town, Miyazaki Prefecture. In the town, four human cases were reported. All of the mice had antibodies against Rickettsia japonica and $R$. montana. The incedence of the antibody was significantly higher in Apodemus mice in the area than in those from nonendemic area.

森田千春·福井正信 (国立予防衛生研究所獣疫部)

山本正悟·川畑紀彦 (宮崎県衛生研究所 宮崎市北高松町5-30)

土屋公幸 (宮崎医科大学動物施設 宮崎郡清武町大字木原 5200 )

吉田芳战·矢部辰男 (神奈川県衛生研究所 横浜市旭区中尾町52) 
Spotted fever group (SFG) rickettsiosis was recently found to be present in Japan. The causative rickettsia was isolated from human patients in Shikoku (1). The incidence of the antibodies against the rickettsia in dogs from the endemic areas was significantly higher than that from nonendemic areas (2). Epidemiological observation revealed that the patients became infected by tick bites during occupational or recreational activities in fields or forests (3). Thus, it is difficult to implicate dogs as the main vertebrate reservoir of the disease. Some rodent species are known to be important natural hosts of SFG rickettsia world wide. In Japan, a major rodent species of the fauna in fields and forests of epidemic areas is Apodemus speciosus. In Miyazaki Prefecture, seven human cases infected with SFG rickettsia have been reported, four of which were from Takaoka town. In this study, an attempt was made to test the presence of the antibody against SFG rickettsia in Apodemus speciosus found in an endemic focus and to compare it with that from a nonendemic area.

In May 1989, 14 Apodemus mice were captured in a bush near the place where one of patients had become infected with SFG rickettsia while 18 Apodemus mice were collected in Yamakita town of Kanagawa Prefecture, where no human SFG rickettsia infection had been recorded. The sera obtained from Apodemus mice were examined by the indirect fluorescent antibody (IFA) test described previously (2). Fluorescein-isothiocyanate conjugated anti rat IgG goat serum (Cappel) was employed. The antibody titers higher than 10 were considered as positive.

All Apodemus mice captured in Takaoka town and four out of 18 from Yamakita town were found to be antiboody positive against $R$. japonica and $R$. montana (Table I). The incidence of the antibody in the endemic focus was significantly higher than that in the nonendemic area $(p<0.01)$ and there was a significant difference between the antibody titers of positive sera from the two areas ( $R$. japonica: $\mathrm{p}<0.01, R$. montana: $\mathrm{p}<0.05$ ). Furthermore, the antibody titers of sera against $R$. japonica from the endemic focus were significantly higher than those against $R$. montana $(\mathrm{p}<0.01)$.

Even in the nonendemic area, some Apodemus mice were found to have antibody against SFG rickettsia. $R$. montana which is a nonpathogenic rickettsia for human beings was isolated from ticks and rodents in the United States (4). Thus, nonpathogenic rickettsia may also be maintained by Apodemus mice in nonendemic areas in Japan.

In Takaoka town, four people became infected either during occupational activities in forests or during recreational activities in fields. The incidence of 
Table I. Prevalence of antibody against spotted fever group rickettisia in Apodemus speciosus in an endemic focus and a nonendemic area

\begin{tabular}{|c|c|c|c|c|c|c|}
\hline \multirow[t]{3}{*}{ Town } & \multirow[t]{3}{*}{$\begin{array}{l}\text { Number } \\
\text { tested }\end{array}$} & \multirow[t]{3}{*}{$\begin{array}{l}\text { Number } \\
\text { positive }\end{array}$} & \multicolumn{4}{|c|}{$\begin{array}{l}\text { Antibody titers } \\
\text { of positive sera } \\
\text { against }\end{array}$} \\
\hline & & & \multicolumn{2}{|c|}{$R$. japonica } & \multicolumn{2}{|c|}{ R. montana } \\
\hline & & & Range & Mean1 & Range & Mean \\
\hline $\begin{array}{l}\text { Takaoka } \\
\text { (endemic) }\end{array}$ & 14 & 14 & $80-5120$ & 951 & $80-2560$ & 430 \\
\hline $\begin{array}{l}\text { Yamakita } \\
\text { (nonendemic) }\end{array}$ & 18 & 4 & $80-320$ & 134 & $20-320$ & 80 \\
\hline
\end{tabular}

1: Geometric mean.

$*$ : $<<0.05$.

$* *: \mathrm{p}<0.01$.

SFG rickettsia antibody was high in Apodemus mice captured near the place where a patient had become infected. Since the antibody titers of the mice against $R$. japonica were significantly higher than against $R$. montana, the rickettsia that infected those mice was thought to be closely related to $R$. japonica isolated from a human patient. In addition, an SPG rickettsia antigenically similar to $R$. japonica has been isolated from one of the 14 Apodemus mice captured in Takaoka town (S. Yamamoto and C. Morita, unpublished data). Apodemus speciosus is likely to be an important vertebrate host for SFG rickettsia in Japan.

\section{ACKNOWLEDGEMENTS}

We wish to express our thanks to Ms. Angie Mumbi Chitambo, Main library, University of Zambia, for her grammatical correction. 


\section{REFERENCES}

1. Uchida, T., Tashiro, F., Funato, T. and Kitamura, Y. (1986): Isolation of spotted fever group rickettsia from a patient with febrile exanthematous illness in Shikoku, Japan. Microbiol., Immunol., 30, 1323-1326.

2. Morita, C., Tsuboi, Y., Iida, A., Mohri, S., Handa, S. and Fukui, M. (1989): Spotted fever group rickettsia in dogs in Japan. Jpn. J. Med. Sci. Biol., 42, 143-147.

3. Narita, H., Tajiri, A., Kawana, N., Asoh, A., Taniguchi, T., Yamagata, H., Gotoh, S. and Hiejima, M. (1988): Spotted fever rickettsiosis (Japanese spotted fever) in Miyazaki Prefecture in particular differential diagnosis from tsutsugamushi disease. Nisi-nihon-hifuka, 50, 853-861 (in Japanese).

4. Philip, R. N., Casper, E. A., Burgdoreer, W., Gerloff, R. K., Hughes, L. E. and Bell, E. J. (1978): Serologic typing of rickettsiae of the spotted fever group by microimmunofluorescence. J. Immunol., 121, 1961-1968. 